\title{
Pengaruh Kepribadian Dan Pengetahuan Kewirausahaan Terhadap Minat Berwirausaha Pada Mahasiswa
}

\author{
Tutut Suryaningsih ${ }^{1}$, Titis Mia Agustin ${ }^{2}$ \\ ${ }^{1,2}$ Program Studi Pendidikan Ekonomi, STKIP PGRI Tulungagung \\ miaagustin98@gmail.com
}

\begin{abstract}
This study aims to find out: (1) The influence of personality on entrepreneurship interests (2) The influence of entrepreneurial knowledge on entrepreneurship interests (3) The influence of personality and entrepreneurial knowledge on the interest in VIII semester student entrepreneurship in Economic Education Study Program STKIP PGRI Tulungagung Academic Year 2018/2019 good simultaneously or partially. This research is quantitative research. The population of this study amounted to 112 students. The sample of this study was 56 students using proportional random sampling method. Data collection techniques using the questionnaire method (questionnaire). The results of data analysis in this study indicate: (1) Partially there is a significant effect of personality on the interest in entrepreneurship with $t_{\text {count }}(7.129)>t_{\text {table }}(2.005)$ with a significance of $0,000<0.05$. (2) Partially there is a significant effect of entrepreneurial knowledge on the interest in entrepreneurship with $t_{\text {count }}(2.032)>t_{\text {table }}(2.005)$ with a significance of 0.047 $<0.05$. (3) Simultaneously there is a significant influence between personality and entrepreneurial knowledge on the interest in entrepreneurship with $F_{\text {count }} \neg(55,591)>$ $F_{\text {table }} \neg(3.17)$ with a significance of $0,000<0.05$. Thus it can be concluded that there is an influence of personality and entrepreneurial knowledge on the interest of VIII semester student entrepreneurship in the Economic Education Study Program of STKIP PGRI Tulungagung Academic Year 2018/2019. The results of this study can be used as reference material for future researchers who discuss personal variables and entrepreneurial knowledge of the interest in entrepreneurship.
\end{abstract}

Keywords: Personality, Entrepreneurship Knowledge, Entrepreneurship Interest

\section{History of Article:}

Received: (02-08-2019),

Accepted : (16-09-2019),

Publised : (24-03-2020)

\section{Citation:}

Suryaningsih, T, Agustin, T.M (2020) Pengaruh Kepribadian Dan Pengetahuan Kewirausahaan Terhadap Minat Berwirausaha Pada Mahasiswa, Jurnal Pendidikan Ekonomi, 13(1), 42-49 


\section{PENDAHULUAN}

Pengangguran merupakan masalah yang sangat rumit bagi setiap negara, tidak terkecuali Indonesia. Menurut data Badan Pusat Statistik (BPS) pada bulan Februari 2018 umlah Tingkat Pengangguran Terbuka di Indonesia mencapai 5,13\% atau turun dari periode yang sama pada tahun sebelumnya sebesar 5,33\%. Dari jumlah persentase itu, maka jumlah pengangguran di Indonesia mencapai 6,87 juta orang atau turun dari tahun sebelumnya mencapai 7,01 juta orang. Melihat tingkat pendidikan, Tingkat Pengangguran Terbuka (TPT) untuk tingkat pendidikan Diploma I/II/II dan Universitas mengalami peningkatan dari jumlah tahun sebelumnya. Jumlah TPT untuk tingkat pendidikan Diploma I/II/III mengalami peningkatan dari 6,88\% pada Agustus 2017 menjadi 7,92\% pada Februari 2018.Jumlah TPT untuk tingkat pendidikan Universitas juga mengalami peningkatan dari 5,18\% pada Agustus 2017 menjadi 6,81\% pada Februari 2018. Meningkatnya angka jumlah pengangguran tersebut disebabkan karena mulai sempitnya lapangan pekerjaan dan angka lulusan serta daftar pencari kerja setiap tahun bertambah jumlahnya.

Masalah di atas sebenarnya dapat diatasi dengan cara menciptakan lapangan pekerjaan atau dengan cara berwirausaha. Menurut Buchari Alma (2013) menyatakan bahwa, "Suatu pernyataan bersumber dari PBB menyatakan bahwa suatu negara akan mampu membangun apabila memiliki wirausaha sebanyak $2 \%$ dari jumlah penduduknya". Namun pada kenyataannya di Indonesia masih sangat rendah minat masyarakat untuk berwirausaha. Sebagian masayarakat Indonesia khususnya mahasiswa lebih memilih mencari pekerjaan bukan untuk menciptakan lapangan pekerjaan. Seperti penjelasan Kasmir (2006) “Orientasi para mahasiswa setelah lulus hanya untuk mencari kerja, bukan menciptakan lapangan kerja “. Untuk menjadi seorang wirausaha haruslah tumbuh minat dalam diri seseorang. Menurut Zimmer, Scarborough dan Wilson (2008) Minat berwirausaha adalah minat yang muncul dari dalam diri seseorang untuk berwirausaha dengan indikator tidak tergantung pada orang lain, membantu lingungan sosial dan perasaan senang menjadi seorang wirausaha.Minat dapat timbul karena rasa ketertarikan dan kekaguman melihat kesuksesan seseorang.

Menurut Bygrave "minat berwirausaha dipengaruhi oleb beberapa faktor diantaranya faktor personal, yang menyangkut aspek kepribadian" (Buchari Alma, 2013). Kepribadian merupakan karakter yang dimiliki oleh seseorang dan tidak persis sama dengan kepribadian orang lain. Lauster berpendapat bahwa sifat yang harus dimiliki seorang wirausahawan adalah kepercayaan pada diri sendiri, berorientasi ke masa depan, dan berani dalam megambil risiko (Sujanto, dkk, 2008). Di dalam kepribadian seseorang terdapat rasa percaya diri, berorientasi pada tugas dan hasil, berani mengambil risiko, berjiwa pemimpin, keorisinian dan berorientasi ke masa depan. Tanpa adanya rasa percaya diri tentu tidak ada minat dari seseorang untuk memutuskan berwirausaha. Selain itu keberanian dalam mengambil risiko juga merupakan tantangan besar bagi seorang wirausaha dalam menjalankan usahanya. Sifat kepemimpinan juga diperlukan dalam menjalankan sebuah usaha. Hal ini didasari dengan tujuan untuk tetap mengarahkan bawahan atau karyawan agar bekerja sesuai dengan tujuan yang telah dikehendaki.

Berdasarkan fakta masih banyak mahasiswa STKIP PGRI Tulungagung khususnya Prodi Ekonomi yang belum berani mengambil resiko untuk melakuan sebuah usaha. Mereka menganggap bahwa berwirausaha memiliki kecenderungan untuk gagal dan belum bisa menjamin masa depan mereka. Mahasiswa juga kurang percaya diri terhadap kemampuan mereka untuk terjun ke dunia bisnis. Meskipun pengetahuan kewirausahaan yang mereka dapatkan pada saat kuliah sangatlah banyak misalnya mata kuliah kewirausahaan, seminar kewirausahaan, UKM kewirausahaan, dan sebagainya. (Ika Prima Melyana, Rusdarti \& Pujiati, 2015) Pengetahuan Kewirausahaan merupakan ilmu, seni, maupun perilaku, sifat, ciri, dan watak seseorang yang mewujudkan gagasan inovatif ke dalam dunia nyata secara kreatif. 
Pengetahuan Kewirausahaan memiliki beberapa indikator antara lain: Komitmen tinggi terhadap tugas, mau bertanggung jawab, kemampuan untuk memimpin. Rifa'atul Maftuhah (2015) menyatakan bahwa "Seseorang yang telah memperoleh pelatihan, mata kuliah, seminar, kursus kewirausahaan akan tertarik untuk berwirausaha". Namun pada kenyataannya dari sekian banyak sumber pengetahuan kewirausahaan yang ada di STKIP PGRI Tulungagung belum sepenuhnya dimanfaatkan sehingga mengakibatkan minat untuk berwirausaha mahasiswa masih rendah. Oleh sebab itulah dalam artikel ini akan dibahas tentang Pengaruh Kepribadian dan Pengetahuan Kewirausahaan terhadap Minat Berwirausaha Mahasiswa Semester VIII Program Studi Pendidikan Ekonomi STKIP PGRI Tulungagung Tahun Akademik 2018/2019”.

\section{METODE}

Penelitian ini menggunakan jenis penelitian kuantitatif korelasional. Sedangkan rancangan penelitian dalam penelitian ini menggunakan rancangan penelitian non eksprimen. Penelitian ini dilakukan di STKIP PGRI Tulungagung dengan jumlah populasi dalam penelitian ini yaitu 112 mahasiswa semester VIII Program Studi Pendidikan Ekonomi tahun Akademik 2018/2019. Sampel dalam penelitian ini sebanyak 56 mahasiswa diambil dengan menggunakan teknik proportional random sampling. Teknik pengumpulan data dalam penelitian ini menggunakan kuisioner (angket) digunakan untuk mengukur variabel kepribadian $\left(\mathrm{X}_{1}\right)$, pengetahuan kewirausahaan $\left(\mathrm{X}_{2}\right)$, dan minat berwirausaha $(\mathrm{Y})$. Analisis data yang disajikan dalam penelitian ini analisisis kuantitatif yang meliputi uji validitas, uji reliabilitas, uji asumsi klasik atau uji prasyarat, uji hipotesis dan uji regresi linier berganda.

\section{HASIL PENELITIAN DAN PEMBAHASAN}

\section{Hasil uji Instrumen}

Instrumen yang digunakan dalam penelitian ini berupa soal angket yang sebelum digunakan dalam penelitian terlebih dahulu dilakukan uji coba instrumen pada 25 responden, untuk mengetahui tingkat validitas dan reliabelitas instrument tersebut. Hasil uji coba instrument (uji validitas dan reliabilitas) dapat dilihat pada tabel berikut.

Tabel 1 Uji Validitas Kepribadian $\left(\mathrm{X}_{1}\right)$

\begin{tabular}{ccclc}
\hline $\begin{array}{l}\text { No } \\
\text { Item }\end{array}$ & $\mathrm{r}_{\text {hitung }}$ & $\mathrm{r}_{\text {tabel }}$ & Keterangan & Kesimpulan \\
\hline 1 & 0,732 & 0,396 & $\mathrm{r}_{\text {hitung }}>\mathrm{r}_{\text {tabel }}$ & Valid \\
\hline 2 & 0,616 & 0,396 & $\mathrm{r}_{\text {hitung }}>\mathrm{r}_{\text {tabel }}$ & Valid \\
\hline 3 & 0,650 & 0,396 & $\mathrm{r}_{\text {hitung }}>\mathrm{r}_{\text {tabel }}$ & Valid \\
\hline 4 & 0,466 & 0,396 & $\mathrm{r}_{\text {hitung }}>\mathrm{r}_{\text {tabel }}$ & Valid \\
\hline 5 & 0,757 & 0,396 & $\mathrm{r}_{\text {hitung }}>\mathrm{r}_{\text {tabel }}$ & Valid \\
\hline 6 & 0,448 & 0,396 & $\mathrm{r}_{\text {hitung }}>\mathrm{r}_{\text {tabel }}$ & Valid \\
\hline 7 & 0,497 & 0,396 & $\mathrm{r}_{\text {hitung }}>\mathrm{r}_{\text {tabel }}$ & Valid \\
\hline 8 & 0,630 & 0,396 & $\mathrm{r}_{\text {hitung }}>\mathrm{r}_{\text {tabel }}$ & Valid \\
\hline 9 & 0,724 & 0,396 & $\mathrm{r}_{\text {hitung }}>\mathrm{r}_{\text {tabel }}$ & Valid \\
\hline 10 & 0,441 & 0,396 & $\mathrm{r}_{\text {hitung }}>\mathrm{r}_{\text {tabel }}$ & Valid \\
\hline 11 & 0,784 & 0,396 & $\mathrm{r}_{\text {hitung }}>\mathrm{r}_{\text {tabel }}$ & Valid \\
\hline 12 & 0,735 & 0,396 & $\mathrm{r}_{\text {hitung }}>\mathrm{r}_{\text {tabel }}$ & Valid \\
\hline 13 & 0,487 & 0,396 & $\mathrm{r}_{\text {hitung }}>\mathrm{r}_{\text {tabel }}$ & Valid \\
\hline 14 & 0,397 & 0,396 & $r_{\text {hitung }}>r_{\text {tabel }}$ & Valid \\
\hline 15 & 0,499 & 0,396 & $r_{\text {hitung }}>r_{\text {tabel }}$ & Valid \\
\hline 16 & 0,410 & 0,396 & $r_{\text {hitung }}>r_{\text {tabel }}$ & Valid \\
\hline 17 & 0,615 & 0,396 & $r_{\text {hitung }}>r_{\text {tabel }}$ & Valid \\
\hline 18 & 0,538 & 0,396 & $r_{\text {hitung }}>r_{\text {tabel }}$ & Valid \\
\hline 19 & 0,784 & 0,396 & $r_{\text {hitung }}>r_{\text {tabel }}$ &
\end{tabular}




$$
20 \quad 0,735 \quad 0,396
$$

Sumber data: Data hasil olahan SPSS, 2019

$r_{\text {hitung }}>r_{\text {tabel }}$

Valid

Tabel 2 Uji Validitas Pengetahuan Kewirausahaan $\left(\mathrm{X}_{2}\right)$

\begin{tabular}{cccll}
\hline $\begin{array}{c}\text { No } \\
\text { Item }\end{array}$ & $\mathrm{r}_{\text {hitung }}$ & $\mathrm{r}_{\text {tabel }}$ & Keterangan & Kesimpulan \\
\hline 1 & 0,697 & 0,396 & $\mathrm{r}_{\text {hitung }}>\mathrm{r}_{\text {tabel }}$ & Valid \\
\hline 2 & 0,421 & 0,396 & $\mathrm{r}_{\text {hitung }}>\mathrm{r}_{\text {tabel }}$ & Valid \\
\hline 3 & 0,545 & 0,396 & $\mathrm{r}_{\text {hitung }}>\mathrm{r}_{\text {tabel }}$ & Valid \\
\hline 4 & 0,789 & 0,396 & $\mathrm{r}_{\text {hitung }}>\mathrm{r}_{\text {tabel }}$ & Valid \\
\hline 5 & 0,843 & 0,396 & $\mathrm{r}_{\text {hitung }}>\mathrm{r}_{\text {tabel }}$ & Valid \\
\hline 6 & 0,803 & 0,396 & $\mathrm{r}_{\text {hitung }}>\mathrm{r}_{\text {tabel }}$ & Valid \\
\hline 7 & 0,780 & 0,396 & $\mathrm{r}_{\text {hitung }}>\mathrm{r}_{\text {tabel }}$ & Valid \\
\hline 8 & 0,509 & 0,396 & $\mathrm{r}_{\text {hitung }}>\mathrm{r}_{\text {tabel }}$ & Valid \\
\hline 9 & 0,803 & 0,396 & $\mathrm{r}_{\text {hitung }}>\mathrm{r}_{\text {tabel }}$ & Valid \\
\hline 10 & 0,561 & 0,396 & $\mathrm{r}_{\text {hitung }}>\mathrm{r}_{\text {tabel }}$ & Valid \\
\hline 11 & 0,699 & 0,396 & $\mathrm{r}_{\text {hitung }}>\mathrm{r}_{\text {tabel }}$ & Valid \\
\hline 12 & 0,681 & 0,396 & $\mathrm{r}_{\text {hitung }}>\mathrm{r}_{\text {tabel }}$ & Valid \\
\hline 13 & 0,712 & 0,396 & $\mathrm{r}_{\text {hitung }}>\mathrm{r}_{\text {tabel }}$ & Valid \\
\hline 14 & 0,720 & 0,396 & $\mathrm{r}_{\text {hitung }}>\mathrm{r}_{\text {tabel }}$ & Valid \\
\hline 15 & 0,572 & 0,396 & $\mathrm{r}_{\text {hitung }}>\mathrm{r}_{\text {tabel }}$ & Valid \\
\hline 16 & 0,691 & 0,396 & $\mathrm{r}_{\text {hitung }}>\mathrm{r}_{\text {tabel }}$ & Valid \\
\hline 17 & 0,776 & 0,396 & $\mathrm{r}_{\text {hitung }}>\mathrm{r}_{\text {tabel }}$ & Valid \\
\hline 18 & 0,849 & 0,396 & $\mathrm{r}_{\text {hitung }}>\mathrm{r}_{\text {tabel }}$ & Valid \\
\hline 19 & 0,655 & 0,396 & $\mathrm{r}_{\text {hitung }}>\mathrm{r}_{\text {tabel }}$ & Valid \\
\hline 20 & 0,766 & 0,396 & $\mathrm{r}_{\text {hitung }}>\mathrm{r}_{\text {tabel }}$ & \\
\hline
\end{tabular}

Sumber data: Data hasil olahan SPSS, 2019

Tabel 3 Uji Validitas Minat Berwirausaha (Y)

\begin{tabular}{|c|c|c|c|c|}
\hline $\begin{array}{c}\text { No } \\
\text { Item }\end{array}$ & $\mathrm{r}_{\text {hitung }}$ & $\mathrm{r}_{\text {tabel }}$ & Keterangan & Kesimpulan \\
\hline 1 & 0,631 & 0,396 & $r_{\text {hitung }}>r_{\text {tabel }}$ & Valid \\
\hline 2 & 0,502 & 0,396 & $r_{\text {hitung }}>r_{\text {tabel }}$ & Valid \\
\hline 3 & 0,719 & 0,396 & $r_{\text {hitung }}>r_{\text {tabel }}$ & Valid \\
\hline 4 & 0,464 & 0,396 & $r_{\text {hitung }}>r_{\text {tabel }}$ & Valid \\
\hline 5 & 0,419 & 0,396 & $\mathrm{r}_{\text {hitung }}>\mathrm{r}_{\text {tabel }}$ & Valid \\
\hline 6 & 0,659 & 0,396 & $r_{\text {hitung }}>r_{\text {tabel }}$ & Valid \\
\hline 7 & 0,685 & 0,396 & $\mathrm{r}_{\text {hitung }}>\mathrm{r}_{\text {tabel }}$ & Valid \\
\hline 8 & 0,509 & 0,396 & $r_{\text {hitung }}>r_{\text {tabel }}$ & Valid \\
\hline 9 & 0,536 & 0,396 & $r_{\text {hitung }}>r_{\text {tabel }}$ & Valid \\
\hline 10 & 0,397 & 0,396 & $r_{\text {hitung }}>r_{\text {tabel }}$ & Valid \\
\hline 11 & 0,667 & 0,396 & $r_{\text {hitung }}>r_{\text {tabel }}$ & Valid \\
\hline 12 & 0,524 & 0,396 & $r_{\text {hitung }}>r_{\text {tabel }}$ & Valid \\
\hline 13 & 0,617 & 0,396 & $r_{\text {hitung }}>r_{\text {tabel }}$ & Valid \\
\hline 14 & 0,631 & 0,396 & $\mathrm{r}_{\text {hitung }}>\mathrm{r}_{\text {tabel }}$ & Valid \\
\hline 15 & 0,685 & 0,396 & $r_{\text {hitung }}>r_{\text {tabel }}$ & Valid \\
\hline 16 & 0,600 & 0,396 & $r_{\text {hitung }}>r_{\text {tabel }}$ & Valid \\
\hline 17 & 0,407 & 0,396 & $r_{\text {hitung }}>r_{\text {tabel }}$ & Valid \\
\hline 18 & 0,496 & 0,396 & $r_{\text {hitung }}>r_{\text {tabel }}$ & Valid \\
\hline 19 & 0,437 & 0,396 & $r_{\text {hitung }}>r_{\text {tabel }}$ & Valid \\
\hline 20 & 0,461 & 0,396 & $r_{\text {hitung }}>r_{\text {tabel }}$ & Valid \\
\hline
\end{tabular}

Sumber: Data hasil olahan SPSS, 2019

Tabel 4 Hasil Uji Reliabilitas Instrumen

Reliability Statistic

45 I Jurnal Pendidikan Ekonomi, Vol.I3, No.I, 2020, Hal. $42-49$ 


\begin{tabular}{lllll}
\hline Variabel & $\begin{array}{l}\text { Alpha } \\
\text { cronbarch's }\end{array}$ & $\begin{array}{l}\text { Koefisien } \\
\text { Reliabilitas }\end{array}$ & Keterangan & Kesimpulan \\
\hline Kepribadian & 0,903 & 0,60 & $0,903>0,60$ & Reliabel \\
\hline $\begin{array}{l}\text { Pengetahuan } \\
\text { Kewirausahaan }\end{array}$ & 0,943 & 0,60 & $0,943>0,60$ & Reliabel \\
\hline Minat Berwirausaha & $0,, 950$ & 0,60 & $0,950>0,60$ & Reliabel \\
\hline
\end{tabular}

Sumber: Data hasil olahan SPSS, 2019

Berdasarkan hasil uji validitas, semua butir soal sebanyak 20 soal dari angket minat berwirausaha nilainya berada lebih dari 0,396 ( $\left.\mathrm{r}_{\text {tabel }}\right)$. Oleh karena nilai $\mathrm{r}_{\text {hitung }}>\mathrm{r}_{\text {tabel }}$ maka angket yang telah disusun dinyatakan valid. Sedangkan hasil uji reliabilitas kepribadian (X1), pengetahuan kewirausahaan (X2) dan minat berwirausaha (Y) yang dianalisis dengan menggunakan analisis Cronbach's Alpha menunjukkan nilai reliabilitas lebih dari 0,60 (batas minimal instrumen di katakan reliabel). Oleh karena itu semua instrumen variabel X1 (kepribadian), X2 (pengetahuan kewirausahaan), dan nilai Y (minat berwirausaha) sudah dapat dikatakan reliabel.

\section{Uji Hipotesis}

Hasil uji hipotesis dalam penelitian ini ditunjukkan dalam tabel berikut ini.

Tabel 5 Hasil Uji t (Parsial)

\begin{tabular}{|c|c|c|c|c|c|}
\hline \multicolumn{6}{|c|}{ Coefficients $^{\mathrm{a}}$} \\
\hline \multirow[t]{2}{*}{ Model } & \multicolumn{2}{|c|}{$\begin{array}{l}\text { Unstandardized } \\
\text { Coefficients }\end{array}$} & \multirow{2}{*}{$\begin{array}{c}\begin{array}{c}\text { Standardized } \\
\text { Coefficients }\end{array} \\
\text { Beta }\end{array}$} & \multirow[b]{2}{*}{$\mathrm{t}$} & \multirow[b]{2}{*}{ Sig. } \\
\hline & B & Std. Error & & & \\
\hline 1 (Constant) & 15,291 & 6,597 & & 2,318 &, 024 \\
\hline KEPRIBADIAN & 634 & 089 & 691 & 7,129 & 000 \\
\hline $\begin{array}{l}\text { PENGETAHUAN } \\
\text { KEWIRAUSAHAAN }\end{array}$ &, 174 & ,086 & , 197 & 2,032 & ,047 \\
\hline
\end{tabular}

a. Dependent Variable: MINAT BERWIRAUSAHA

Sumber: Data olahan SPSS, 2019

Tabel 6 Hasil Uji F

ANOVA $^{b}$

\begin{tabular}{llrrrrr}
\hline Model & & \multicolumn{2}{c}{ Mean } & \\
& & Sum of Squares & df & Square & F & Sig. \\
\hline 1 & Regression & 1186,999 & 2 & 593,500 & 55,591 &, $000^{\mathrm{a}}$ \\
& Residual & 565,840 & 53 & 10,676 & & \\
& Total & 1752,839 & 55 & & & \\
\hline
\end{tabular}

a. Predictors: (Constant), PENGETAHUAN KEWIRAUSAHAAN, KEPRIBADIAN

b. Dependent Variable: MINAT BERWIRAUSAHA

Sumber: Data olahan SPSS, 2019

Berdasarkan hasil uji hipotesis menggunakan uji t, dijelaskan bahwa hasil uji variabel kepribadian $\left(\mathrm{X}_{1}\right)$ terhadap minat berwirausaha $(\mathrm{Y})$ memiliki nilai sig. $\mathrm{t}<$ alpha yaitu sebesar $0,000<0,05$ dan $t_{\text {hitung }}>t_{\text {tabel }}$ yaitu sebesar 7,129 $>2,00575$. Dengan demikian dapat dikatakan bahwa terdapat pengaruh yang signifikan antara kepribadian $\left(\mathrm{X}_{1}\right)$ terhadap minat berwirausaha (Y) mahasiswa semester VIII Program Studi Pendidikan Ekonomi STKIP PGRI Tulungagung tahun akademik 2018/2019. Selanjutnya untuk hasil uji variabel pengetahuan kewiraushaan $\left(\mathrm{X}_{2}\right)$ terhadap minat berwirausaha $(\mathrm{Y})$ memiliki nilai sig. $\mathrm{t}<$ alpha yaitu sebesar $0,047<0,05$ dan $t_{\text {hitung }}>t_{\text {tabel }}$ yaitu sebesar $2,032>2,00575$. Oleh sebab itu dapat dikatakan bahwa terdapat pengaruh yang signifikan antara pengetahuan 
kewirausahaan $\left(\mathrm{X}_{2}\right)$ terhadap minat berwirausaha $(\mathrm{Y})$ mahasiswa semester VIII Program Studi Pendidikan Ekonomi STKIP PGRI Tulungagung tahun akademik 2018/2019.

Sedangkan berdasarkan hasil uji hipotesis yang diambil dari hasil uji F, menunjukkan bahwa nilai $F_{\text {hitung }}(55,591)>F_{\text {tabel }}(3,17)$ dan tingkat signifikan $0,000<0,05$ sehingga hipotesis nol di tolak dan hipotesis alternatif diterima. Oleh karena itu, dapat disimpulkan bahwa $\mathrm{H}_{0}$ dalam penelitian ini di tolak dan $\mathrm{H}_{\mathrm{a}}$ di terima yang berarti terdapat pengaruh yang signifikan antara variabel kepribadian dan gaya hidup terhadap perilaku konsumtif mahasiswa Program Studi Pendidikan Ekonomi semester VIII STKIP PGRI Tulungagung tahun akademik 2018/2019 secara simultan.

Dari table 5 dan 6 disusun persamaan regresi $Y=15,291+0,634 X_{1}+0,174 X_{2}$. Persamaan ini sesuai dengan rumus persamaan regresi $Y=a+b_{1} X_{1}+b_{2} X_{2}$ (Riduwan, 2011). Koefisien regresi dari $\mathrm{X}_{1}\left(\mathrm{~b}_{1}\right)$ sebesar 0,634 menunjukkan bahwa setiap penambahan satu satuan variabel X1 dengan asumsi variabel lain (X2) konstan akan berpengaruh terhapap peningkatan besarnya $\mathrm{Y}$ sebesar 0,634 . Begitu juga dengan koefisien regresi dari $\mathrm{X}_{2}\left(\mathrm{~b}_{2}\right)$ sebesar 0,174 , mengandung arti bahwa setiap penambahan satu satuan variabel $\mathrm{X}_{2}$ dengan asumsi variabel lain $\left(\mathrm{X}_{1}\right)$ konstan maka hal ini akan berpengaruh peningkatan besarnya $\mathrm{Y}$ sebesar 0,174 .

\section{Pengaruh Kepribadian Terhadap Minat Berwirausaha}

Berdasarkan hasil analisis diperoleh $t_{\text {hitung }}(7,129)>t_{\text {tabel }}(2,00575)$ dengan signifikasi $0,000<0,05$ dengan begitu dapat disimpulkan bahwa $\mathrm{H}_{0}$ ditolak $\mathrm{H}_{\mathrm{a}}$ diterima. Ada pengaruh positif dan signifikan antara kepribadian terhadap minat berwirausaha mahasiswa. Hal ini dapat diartikan jika semakin tinggi kepribadian mahasiswa pendidikan ekonomi maka semakin tinggi minat untuk berwirausaha. Sebaliknya semakin rendah kepribadian mahasiswa pendidikan ekonomi maka semakin rendah minat berwirausaha.

Hasil tersebut sesuai dengan indikator dari variabel kepribadian yang dijelaskan oleh Lauster yaitu 1) Kepercayaan pada diri sendiri 2) Ketahan menghadapi cobaan 3) Berani dalam mengambil resiko (Sujanto, 2004). Dari tiga indikator tersebut, indikator nomor satu yaitu kepercayaan kepada diri sendiri yang memberikan pengaruh hasil paling besar dari pada indikator lainnya. Sedangkan untuk indikator variabel minat berwirausaha peneliti menggunakan indikator menurut Zimmerer, Scarborough \& Wilson (2008) yaitu: 1) Tidak tergantung pada orang lain 2) Mambantu lingkungan sosial 3) Perasaan senang menjadi wirausaha. Dari tiga indikator tersebut indikator nomor tiga yaitu perasaan senang menjadi wirausaha yang memberikan pengaruh hasil paling besar dari pada indikator lainnya .

\section{Pengetahuan Kewirausahaan Terhadap Minat Berwirausaha}

Berdasarkan hasil analisis diperoleh $t_{\text {hitung }}(2,032)>t_{\text {tabel }}(2,00575)$ dengan signifikasi $0,047<0,05$ dengan begitu dapat disimpulkan bahwa $\mathrm{H}_{0}$ ditolak $\mathrm{H}_{\mathrm{a}}$ diterima. Ada pengaruh positif dan signifikan antara pengetahuan kewirausahaan terhadap minat berwirausaha . Hal ini dapat diartikan jika semakin tinggi pengetahuan kewirausahaan maka semakin tinggi minat berwirausaha. Sebaliknya semakin rendah pengetahuan kewirausahaan maka semakin rendah minat berwirausaha.

Dalam penelitian ini peneliti menggunakan indikator variabel pengetahuan kewirausahaan menurut Melyana et al., (2015) yaitu 1) Komitmen tinggi terhadap tugas, 2) Mau bertanggung jawab 3) Kemampuan untuk memimpin . Dari tiga indikator tersebut, indikator nomor dua yaitu indikator mau bertanggung jawab yang memberikan pengaruh hasil paling besar dari pada indikator lainnya. Sedangkan untuk indikator minat berwirausaha peneliti menggunakan indikator menurut Zimmerer, Scarborough \& Wilson, (2008) yaitu: 1) Tidak tergantung pada orang lain 2) Mambantu lingkungan sosial 3) Perasaan senang menjadi wirausaha. Dari tiga indikator tersebut indikator nomor tiga yaitu 
perasaan senang menjadi wirausaha yang memberikan pengaruh hasil paling besar dari pada indikator lainnya .

\section{Pengaruh Kepribadian dan Pengetahuan Kewirausahaan terhadap Minat Berwirausaha}

Berdasarkan hasil analisis data diperoleh hasil $F_{\text {hitung }}(55,591)>F_{\text {tabel }}(3,17)$ dan tingkat signifikan $0,000<0,05$. Dengan demikian $\mathrm{H}_{\mathrm{o}}$ ditolak dan $\mathrm{H}_{\mathrm{a}}$ diterima. Ada pengaruh positif dan signifikan antara kepribadian dan pengetahuan kewirausahaan terhadap minat berwirausaha. Hal ini dapat diartikan jika semakin tinggi kepribadian dan pengetahuan kewirausahaan maka semakin tinggi minat berwirausaha. Sebaliknya semakin rendah kepribadian dan pengetahuan kewirausahaan maka semakin rendah minat berwirausaha.

Dalam penelitian ini peneliti menggunakan indikator variabel kepribadian menurut Lauster yaitu 1) Kepercayaan pada diri sendiri 2) Ketahan menghadapi cobaan 3) Berani dalam mengambil resiko (Sujanto, 2006). Dari tiga indikator tersebut, indikator nomor satu yaitu kepercayaan kepada diri sendiri yang memberikan pengaruh hasil paling besar dari pada indikator lainnya. Untuk indikator variabel pengetahuan kewirausahaan menurut Melyana et al., (2015) yaitu 1) Komitmen tinggi terhadap tugas, 2) Mau bertanggung jawab 3) Kemampuan untuk memimpin . Dari tiga indikator tersebut, indikator nomor dua yaitu indikator mau bertanggung jawab yang memberikan pengaruh hasil paling besar dari pada indikator lainnya. Sedangkan untuk indikator variabel minat berwirausaha peneliti menggunakan indikator menurut Zimmerer, Scarborough \& Wilson (2008) yaitu : 1) Tidak tergantung pada orang lain 2) Mambantu lingkungan sosial 3) Perasaan senang menjadi wirausaha. Dari tiga indikator tersebut indikator nomor tiga yaitu perasaan senang menjadi wirausaha yang memberikan pengaruh hasil paling besar dari pada indikator lainnya .

Berdasarkan hasil uji regresi linier berganda, Koefisien Determinasi diperoleh hasil perhitungan secara simultan besarnya pengaruh kedua variabel bebas (kepribadian dan pengetahuan kewirausahaan) terhadap variabel terikat (Minat berwirausaha) yaitu sebesar 0,665. Hal ini menunjukkan bahwa 66,5 \% perubaan variabel minat berwirausaha (Y) dipengaruhi oleh kepribadian $\left(\mathrm{X}_{1}\right)$ dan pengetahuan kewiraushaan $\left(\mathrm{X}_{2}\right)$, sedangkan sisanya dipengaruhi oleh faktor-faktor lain diluar vaiabel dalam penelitian ini. Jadi dapat di simpulkan bahwa kepribadian dan pengetahuan kewirausahaan berpengaruh positif dan signifikan secara simultan terhadap minat berwirausaha mahasiswa semester VIII program studi pendidikan ekonomi STKIP PGRI Tulungagung tahun akademik 2018/2019.

\section{KESIMPULAN}

Berdasarkan hasil analisis data dapat disimpulkan bahwa: 1) terdapat pengaruh yang kepribadian $\left(\mathrm{X}_{1}\right)$ terhadap minat berwirausaha $(\mathrm{Y})$ mahasiswa semester VIII Program Studi Pendidikan Ekonomi STKIP PGRI Tulungagung tahun akademik 2018/2019; 2) terdapat pengaruh pengetahuan kewirausahaan (X2) terhadap minat berwirausaha (Y) mahasiswa semester VIII Program Studi Pendidikan Ekonomi STKIP PGRI Tulungagung tahun akademik 2018/2019; 3) terdapat pengaruh kepribadian (X1) dan pengetahuan kewirausahaan (X2) terhadap minat berwirausaha (Y) mahasiswa semester VIII Program Studi Pendidikan Ekonomi STKIP PGRI Tulungagung tahun akademik 2018/2019. 


\section{DAFTAR RUJUKAN}

Alma, B (2013) Kewirausahaan, Cetakan ketujuh belas.Bandung:Alfabeta

Badan Pusat Statistik (2019) Pengangguran Terbuka Menurut Pendidikan Tertinggii yang Ditamatkan 2017-2018, (Online), [www.bps.go.id], diakses 3 Februari 2019.

Kasmir (2006) Kewirausahaan. Jakarta: PT Rajawali Pers

Maftuhah, R (2015) Pengaruh Efikasi diri, Lingkungan Keluarga, Dan Pengetahuan Kewirausahaan Terhadap Minat Berwirausaha Siswa SMK di Sidoarjo.Jurnal Ekonomi pendidikandan krwirausahaan, 3(1), 121-131

Melyana, I P.Rusdarti,\& Pujiati, A (2015) Pengaruh Sikap Dan Pengetahuan Kewirausahaan Terhadap Kesiapan Berwirausaha Melalui Self-Efficacy. Journal of Economic Education (Jee), 4 (1), 8-13, Retrived from [http://journal.unnes.ac.id/sju/index.php./jeec]

Riduwan (2011) Skala Pengukuran Variabel-Variabel Penelitian Bandung: Alfabeta.

Scarborough, N., Wilson, D., Zimmerer, T (2008) Kewirausahaan Dan Manajemen Usaha Kecil. Jakarta: Salemba empat

Sujanto, A, dkk (2008) PsikologiKepribadian,(Jakarta:PT Bumi Putra Aksara,) 